Research Report

\title{
Educational Comic for Dental Caries Prevention in Kalijudan 1 Elementary School, Surabaya
}

\author{
Agung Sosiawan, Taufan Bramantoro, Aisyah Rachmadani Putri Gofur, Dida Devina and Ni Nyoman Astari \\ Kumala Dewi \\ Departement Dental Public Health, \\ Faculty of Dental Medicine, Universitas Airlangga \\ Surabaya - Indonesia
}

\begin{abstract}
Background: Dental caries is one of the dental and oral diseases, and it is caused by S. mutans. Almost all humans have dental caries, and it is a burden disease in Indonesia. The prevalence of dental caries is $79.1 \%$ worldwide, and the prevalence of child dental caries in Indonesia was 92.6\% in 2018. Purpose: To promote child dental health awareness in children through an educational comic. Methods: Educational comics were distributed directly to students of Kalijudan Elementary School. Tools and materials of the empowerment program: Stationery, Laptop/computer, Application to layout the comic. There are 13 teachers and 30 students involved in this program. The students were given pre-test before learned about dental health from educational comics. After receiving health education materials from the comics books, they were given post-test to measure the increasement of health knowledge. Pre and post test data were analyzed with Paired-T test. Results: The pre-test and post-test results of the empowerment program at Kalijudan 1 elementary school were 12.3 and 13.6, respectively. There was a 1.3 point increase. The significance value was 0.000 ( $p$-Value $<0.05)$. This means that there was a significant difference in children's knowledge levels before and after they read the comic. Conclusion: The result showed that children have learned that dental and oral health affects physical activities.
\end{abstract}

Keywords: Caries; physical activity; educational comic

Correspondence: Agung Sosiawan. Department of Dental Public Health, Faculty of Dental Medicine, Universitas Airlangga, J1. Prof. Dr. Moestopo 47 Surabaya 60132 - Indonesia. Email: agung-s@fkg.unair.ac.id

\section{INTRODUCTION}

Dental caries index (angka karies gigi) shows the dental and oral health status of a community, and almost all human beings have dental caries. ${ }^{1}$ Dental caries is one of the dental and oral diseases caused by $S$. mutans, and it is a burden disease in Indonesia. Dental and oral health status, in this case, dental caries, is represented with DMF-T index (Decay Missing Filled Teeth). DMF-T index represents the total of teeth with caries in a person or a community. D represents decayed teeth due to caries, $M$ represents missing teeth due to dental caries, and $\mathrm{F}$ represents filled teeth due to caries. The DMF-T formula is D $\mathrm{M}+\mathrm{F}^{2,3}$

The prevalence of caries is $79.1 \%$ worldwide, ${ }^{4}$ and the prevalence of caries in 5-9 years old children in Indonesia is $92.6 \%{ }^{5}$ Caries is the main dental health problem in children. Cavities or dental caries is a progressive of tooth decay that starts from the surface of a tooth or enamel into the dentin. ${ }^{6,7}$
People generally assume that milk teeth do not need care because permanent teeth will replace them. This exposes children to a toothache that affects their chewing functions, affects their food intake, and promotes malnutrition. ${ }^{8}$ As the future of a nation, children, especially those in elementary school age, need nutritious food intake for optimal growth. Physical fitness means a set of attributes related to the ability to perform physical activity. The construct of physical fitness consists of various dimensions, including body composition and muscle performance. Regular physical activity and physical fitness related to health are the main indicators of health outcomes. ${ }^{9,10}$ It has been well documented that regular PA helps maintain a healthy weight, reduce the risk of diabetes, hypertension, and cardiovascular disease, and improve emotional control and stress. ${ }^{10,11}$

Increased physical fitness related to health, including the health of the cardiovascular system, muscle strength and endurance, flexibility, and body composition, is conducive to improving health. For example, a healthy level of 
Indonesian Journal of Dental Medicine Volume 2 Issue 1 2019; 1-3

cardiovascular endurance is positively related to a healthier cardiovascular profile in children. ${ }^{12,13}$ Children with healthy cardiovascular endurance levels also have lower overall adiposity, abdominal adiposity, and lower metabolic risk. Hurtig-Wennlöf et al. found that cardiovascular fitness was more strongly associated with defining a healthy cardiovascular profile and was more negatively related to risk factors for cardiovascular disease than physical activity measured objectively in children. ${ }^{9}$ reported that muscle strength/endurance was also associated with established and emerging risk factors for cardiovascular disease. Also, increased muscle strength/endurance and flexibility have a more positive effect on bone health compared to cardiovascular endurance. ${ }^{14}$ As a result, physical fitness is directly affected by body fat accumulation and muscle metabolism.

Damage to muscles, which can decrease physical fitness, induces a chain of events involving leukocytes and increased levels of serum proinflammatory cytokines, such as interleukin IL-1 $\beta$, IL-6, and tumor necrosis factor TNF- $\alpha$. This inflammatory response in muscles can cause secondary damage to healthy muscle structure, prolonging the muscle repair process, increasing muscle pain, and making individuals more reluctant to contract their skeletal muscles. ${ }^{15}$ Physical activity is one of the factors that can affect a child's growth and development. American Diabetic Association (2000), stated that carbohydrate, protein, and fat requirements are essential nutrients for daily activities. The amount of carbohydrate, protein, and fat needed is proportional to the intensity of physical exercise, time, frequency, age, and sex. This study aimed to look at the oral health status and physical activity of elementary school students at the Kalijudan Public Health Center coverage.

\section{MATERIALS AND METHODS}

The target of this empowerment program is the students of Kalijudan Elementary School. The educational comic was designed for children to encourage them to maintain their dental health. The empowerment program involved a stakeholder/dentist of the Kalijudan Public Health Center in promoting child dental health. The objective of this empowerment program was to educate children about dental and oral health. The education material was delivered in the form of an educational comic. Educational comics were distributed directly to students of Kalijudan Elementary School. Tools and materials of the empowerment program: stationery, laptop/computer and application to layout the comic.

\section{RESULTS}

The program was conducted on 19 September 2019 at Kalijudan 1 Elementary School under Kalijudan Public Health Center coverage involving 13 teachers as respondents. This program was carried out to promote
Table 1. Paired T-Test

\begin{tabular}{llcc}
\hline & $\mathrm{N}$ & Mean & p-value \\
\hline Pre-test & 30 & & \\
Post-test & 30 & -1.33 & 0.000 \\
\hline
\end{tabular}

child dental and oral health because decayed teeth would affect physical activity. The program was evaluated on the same day. The evaluation result of the program is a comparison between pre-test and post-test scores. Pre-test and post-test questions were adapted from an education comic with the title "Otot Kuat karena Gigi Sehat". There were 10 questions. The mean of pre-test was 12.3, and the mean of post-test scores was 13.6. The score increased by 1.3. A paired t-test was then performed to see the relation between the two variables. The results are presented in the Table 1 .

The result of the paired t-test was -1.33 - minus means that there was an increase. The significance value was 0.000 ( $\mathrm{p}$-Value $<0.05$ ). This means that there was a significant increase after the students read the comic.

\section{DISCUSSION}

An epidemiological study of Kalijudan 1 Elementary School students reported that there was a significant relationship between the DMF-T score and students' physical activities. This research has confirmed that children with higher caries scores tend to have less physical activity.

The program aimed to educate the students about dental and oral health. The empowerment program implemented an indirect approach by providing the students with presumably interesting media, educational comics.

Dental and oral health education is a critical component of health services. The program was expected to educate the students about dental and oral health and encourage them to adopt healthier behavior. ${ }^{16}$

Visual media has a long-term impact on the population, and there has been significant development in visual and audio-visual media. Such development supports children's potential because, by nature, they learn more through visual perception. Other than visual, engaging media would also contribute to the success of learning. This is intended to make the students enthusiastic that the information would be remembered easily. One of the media is an educational comic. Comic means reading material where children are expected to read voluntarily. This is presumes that comic stories are easier to understand because they are visualized. Comic as a reading material has benefitted developed countries in increasing children's interest in reading. In fact, comics have become a very effective learning media and is very attractive to students with because it visualizes and delivers information in plain language. ${ }^{17}$

Therefore, an empowerment program was created to ease access to information. This was an indirect empowerment 
Indonesian Journal of Dental Medicine Volume 2 Issue 1 2019; 1-3

program because it was conducted through media, an educational comic.

The 12-page educational comic tells two contrast stories about the dental health of elementary school students. The conflict was in the middle of the story, telling that the student who did not care for his dental health failed in a futsal competition. On the other hand, the student who maintains her dental health won a dancing competition. At the end of the story, both students maintain their dental health because they learned that dental health affects their physical activities. The comic was distributed on Thursday, 19 September 2019.

\section{CONCLUSION}

After conducting an empowerment program, this educational comic has been received and read by 30 children. The comparison between pre-test and post-test scores shows that there was a 1.3 increase. This indicates that the students have learned about maintaining dental and oral health and its impact on physical activities.

\section{REFERENCES}

1. Carranza FA, Newman MG, Takei HH, Klokkevold PR. Carranza's clinical periodontology. 2006. 110-19, 344-70 p.

2. Hobdell M, Petersen PE, Clarkson J, Johnson N. Global goals for oral health 2020. Int Dent J. 2003;53(5):285-8.

3. Sundoro EH. Serba-Serbi Ilmu Konsevasi Gigi. Jakarta: Universitas Indonesia; 2007. 32-172 p.

4. Ballouk MAH, Dashash M. Caries prevalence and dental health of 8-12 year-old children in Damascus city in Syria during the Syrian Crisis; a cross-sectional epidemiological oral health survey. BMC Oral Health. 2019 Jan 15;19(1).

5. Badan Penelitian dan Pengembangan Kesehatan Kementerian RI. Riskesdas Tahun 2018. Jakarta: Kementrian Kesehatan Republik Indonesia; 2018.

6. Harty F., R.Ogston. Kamus Kedokteran Gigi. Jakarta: Jakarta : EGC; 1995. 384 p.
7. Proffit; WR, Fields HW, Sarver DM. Contemporary Orthodontics, 5th ed. Philadelphia: Elsevier; 2013.

8. Anderson AK, Bignell W, Winful S, Soyiri I, Steiner-Asiedu M. Risk Factors for Malnutrition among Children 5-years and Younger in the Akuapim-North District in the Eastern Region of Ghana. Curr Res J Biol Sci. 2010;2(3):183-8.

9. Ortega FB, Ruiz JR, Castillo MJ, Sjöström M. Physical fitness in childhood and adolescence: A powerful marker of health. Vol. 32, International Journal of Obesity. Int J Obes (Lond); 2008. p. 1-11.

10. Blair SN, Cheng Y, Scott Holder J. Is physical activity or physical fitness more important in defining health benefits? In: Medicine and Science in Sports and Exercise. Med Sci Sports Exerc; 2001.

11. Rauner A, Mess F, Woll A. The relationship between physical activity, physical fitness and overweight in adolescents: A systematic review of studies published in or after 2000. BMC Pediatr. 2013 Feb 1;13(1).

12. Ruiz JR, Ortega FB, Meusel D, Sjöström M. Traditional and novel cardiovascular risk factors in school-aged children: A call for the further development of public health strategies with emphasis on fitness. In: Journal of Public Health. Springer; 2007. p. 171-7.

13. Hurtig-Wennlöf A, Ruiz JR, Harro M, Sjöström M. Cardiorespiratory fitness relates more strongly than physical activity to cardiovascular disease risk factors in healthy children and adolescents: The European Youth Heart Study. Eur J Cardiovasc Prev Rehabil. 2007 Aug;14(4):575-81.

14. Chen CH, Nosaka K, Chen HL, Lin MJ, Tseng KW, Chen TC. Effects of flexibility training on eccentric exerciseinduced muscle damage. Med Sci Sports Exerc. 2011 Mar;43(3):491-500.

15. Santos TRT, Oliveira BA, Ocarino JM, Holt KG, da Fonseca ST. Effectiveness of hip muscle strengthening in patellofemoral pain syndrome patients: A systematic review. Brazilian J Phys Ther. 2015 Jul 14;19(3):167-76.

16. Bankole OO, Ibiyemi O, Oke GA. A dental health education video for Nigerian children in the Yoruba language. African J Biomed Res. 2011;14(1):77-9.

17. Listiyani IM, Widayati A. Pengembangan Komik Sebagai Media Pembelajaran Akuntansi Pada Kompetensi Dasar Persamaan Dasar Akuntansi Untuk Siswa Sma Kelas XI. J Pendidik Akunt Indones. 2012 Nov 1;10(2). 